\title{
Policy Transformations and Institutional Interventions Regarding VET in an Employment-oriented European Union
}

\author{
Sofia Boutsiouki ${ }^{1}$ \\ ${ }^{1}$ Department of International and European Studies, University of Macedonia, Thessaloniki, Greece \\ Correspondence: Sofia Boutsiouki, Department of International and European Studies, University of Macedonia, \\ 156 Egnatia street, P.O. Box 1591, 54006 Thessaloniki, Greece. Tel: 30-694-906-9220. E-mail: \\ sofiab@uom.edu.gr
}

\author{
Received: January 7, 2014 Accepted: February 13, 2014 Online Published: February 27, 2014 \\ doi:10.5539/res.v6n1p201 URL: http://dx.doi.org/10.5539/res.v6n1p201
}

\begin{abstract}
During the last two decades the international socioeconomic circumstances have changed dramatically. The European Union has engaged in an effort to achieve socioeconomic adjustments in an attempt to confront the changes in the international environment, especially the persisting financial crisis. Many European Union policies were reoriented due to the socioeconomic transformations; among others, greater emphasis was given to the promotion of an innovative spirit in Vocational Education and Training (VET). This paper aims at discussing the main legislative interventions and institutional tools through which the European Union pursues the reorganisation of VET systems in terms of operation and quality. The importance of these initiatives is strongly related to the ability of the member states to ignite development actions and economic growth. The paper also attempts to assess the aspirational character and the prospects of success of such policy initiatives to increase the opportunities of European citizens for educational and employment mobility. These EU interventions aspire to increase the opportunities of Europeans to be educated or trained, to develop their competences, to broaden their knowledge and creative spirit by accessing multiple educational environments, to take advantage of professional opportunities in the common European area. In the long-run this will serve to invigorate the economic potential of the European economy and contribute not only to the European integration, but also to the confrontation of social turmoil.
\end{abstract}

Keywords: European Union policy, European institutions, employment, vocational education and training, employment mobility, educational mobility

\section{Introduction}

During the last two decades dramatic changes in the socioeconomic circumstances have altered the balance of power in the international arena where new economic players have appeared (Note 1). The European Union has engaged in an effort to achieve socioeconomic adjustments in an attempt to confront the changes in the international environment, especially the persisting financial crisis; the basic aims are the halt of the declining economic figures, the improvement of the international EU performance and the guaranteed return to sustainable growth. Many European Union policies were reoriented due to socioeconomic transformations; among others, greater emphasis was given to the promotion of an innovative spirit in Vocational Education and Training (VET).

This paper aims at discussing the main legislative interventions and institutional tools which were created by the EU. These tools are expected to contribute to the reorganisation of VET systems and to facilitate educational and employment mobility. The paper also attempts to assess the aspirational character and the prospects of success of such policy initiatives to increase the available opportunities of European citizens to learn or work in other parts of Europe. In the long-run this will serve to invigorate the economic potential of the European economy and contribute not only to the European integration, but also to the confrontation of social turmoil.

\section{Theoretical Framework}

The role of VET in the national education systems and its importance for development always causes broad discussions. The debate regarding VET policies occasionally focuses on the economic aspects of the issue, while in other cases the issue is challenged from a social perspective. 
The human capital approach argues that knowledge and skills acquired through education are a very important component of human capital (Becker, 1994). Moreover, in combination with other policies, all forms of learning are able to exploit relevant investment and benefit the productivity of individuals and, consequently, the economic development of a country (Schultz, 1981). From this point of view, VET is considered essential for economic growth, because, by developing the necessary job-related skills and competencies, it increases the potential of the workforce in terms of productivity and employability and contributes to addressing the needs of the labour market. In fact, if such an investment on human capital is neglected, then national economies are expected to face serious socioeconomic difficulties (Becker, 1994, 1995; Harbison, 1973; Harbison \& Meyers, 1964; Schultz, 1971).

Education and training can also influence the social, cultural and personal capital of individuals (Côté, 2005; Feinstein et al., 2008). As a consequence, it has been seen as a means for combating poverty and social exclusion and, thus, improving the situation in social cohesion conditions. Yet, more or less significant differences may appear between countries provoked by diversities in national socioeconomic circumstances (Cedefop, 2013, 2014; Crossley \& Jarvis, 2001).

Although investment in VET as a tool for development and growth has been considered a key issue by international organisations, its actual effectiveness was often challenged not unjustifiably. In fact, the academic debate on the role of VET on development was postponed for many years for various reasons, either shifting the focus away from it or questioning its efficiency and effectiveness (McGrath, 2012). The United Nations Millennium Development Goals (MDGs) are an example of VET often being neglected; they focused mainly on primary and basic education and declared that VET was not so important for the development of countries (Middleton, Ziderman, \& Van Adams, 1992).

Nevertheless, along with other changes in the international environment, the belief that productivity and economic growth would be positively affected by an investment on education (including VET) gained momentum. Previous experience has been incorporated in a new approach for VET in order to address not only present, but also future social and labour challenges mainly. Therefore, the traditional view has evolved into the need to ensure better VET responsiveness, accountability and attractiveness to labour markets. Moreover, issues of promoting fairness and equality-through improved access and inclusion in learning or working environmentsand transformation in VET-so that it is able to incorporate initiatives for lifelong learning, innovation, sustainability and individual well-being-indicate the urgency for a VET able to adjust and function within a broader societal context (Allais, 2010; UNESCO, 2012a, 2012b, 2012c; UN General Assembly, 2001; World Bank, 1991).

Within this context a VET toolkit was developed and promoted for implementation in most countries, involving systemic governance reforms. These structural changes expand the power for policy guidance beyond the state to employers too, aspiring a more close relation of VET to the labour market. Also, other initiatives were set up, such as national qualifications frameworks, quality assurance systems, new funding mechanisms and greater, but managed autonomy for public providers, who nevertheless, are obliged to respond to specific national policy directions and to reach targets, while at the same time they are subject to monitoring and assessment (McGrath, 2012). Despite the fair recognition by policy makers, many academics argue that this toolkit cannot be fully operational and effective. Instead, greater attention should be paid to the particular national contexts where VET reforms are to be implemented (Allais, 2010; McGrath \& Lug, 2012). Besides, it must be emphasized that the ability of all forms of education and training to ignite an employment increase is limited and, thus, employment frameworks cannot depend exclusively on education policies.

The debate regarding the development of VET policies has an additional aspect. The focus on investing in human capital and promoting the creation of skills with an employment orientation has been related with the need of economies to develop a competitive advantage through ensuring a high-skilled work-force in a very unfavourable global environment. For decades the state undertook all VET provisions and regulations. Gradually it became visible that the reforms and the development of VET especially should overcome their public orientation and shift their focus towards a market-based approach. Nevertheless, the public role in defining and providing VET interventions remained in the hands of the state for realistic and practical reasons (McGrath, 2012, p. 625). It should also be underlined that the public agencies undertake more proactive roles in communicating with the business sector and establishing a leading role in regulating and certifying educational services (Crouch, Finegold, \& Sako, 1999; Lloyd \& Payne, 2002).

In spite of strong arguments favouring the economic role of VET, the debate was supplemented by challenging the idea of a market-based approach for VET. VET is accused of implementing a curriculum that is over-focused 
on labour market demands. Although a vocationally-oriented curriculum can actively increase the benefits of such a study-option for students, it should be mentioned that a strictly vocational study programme often runs the danger of being less esteemed or outdated and, thus, less attractive. For this reason it has to be enriched with more generic content too, which allows for better communication with other parts of the educational system, while at the same time more applied learning could be introduced in general education (McFarland \& Vickers, 1994; Mouzakitis, 2010; Psacharopoulos, 1997). In addition, studies show that the employment prospects of students seem to increase when the education and training programmes combine general/academic and vocational education or even offer them the opportunity to qualify either for tertiary education studies or for immediate entrance in the labour market (Durand-Drouhin, McKenzie, \& Sweet, 1998; OECD, 1998; Unesco, 2012a, 2012c).

Moreover, the intense focus attributed by VET interventions on employment (in terms of conditions or future prospects) led many academics to criticise VET for disconnecting the students' interest from other aspects of life (social, cultural, personal). Instead, VET is considered to adopt an almost-exclusively professional focus and to associate it to labour market demands and to processes of production (Anderson, 2009; Giddens, 1994). Students' general education is put aside; thus, important life skills, necessary broader cultivation, well-being and citizenship are neglected, although they constitute meaningful facets for individuals' lives. Human nature is complex; hence education and training should not be one-sided. So, VET should at least include such content and aims (Anderson, 2009; McGrath, 2012; Psacharopoulos, 1997).

\section{The European Union Perspective}

\subsection{European Union Employment Policies and VET}

Over the years it has been broadly argued-by supranational formations especially-that a successful VET system has a multidimensional effect on the economic and broader social dynamics. It enhances an individual's professional skills and competencies; at the same time it develops the adaptability and flexibility of the existing and the potential labour force to technological change, thus securing numerous advantages for both the individual and the economy. VET also has a significant contribution to the competitiveness of an economy by securing higher productivity and quality and decreasing the labour costs. It is in the position to provide a fair and meritocratic allocation of individuals in the appropriate job positions. Consequently, it ensures a higher added value for employees, strengthens teamwork and cooperation and offers opportunities for professional advancement. It can also connect personal and corporate performance by creating the appropriate conditions for innovation and the undertaking of initiatives in the working environment. It should not be overlooked that such a system constitutes a form of individual investment which aims at one's personal and social empowerment and fulfillment, cultivation of skills and smoother social transitions. It contributes to the formation of a new knowledge and information-oriented culture. Last but not least VET appears to have the strongest potential against unemployment -or other forms of employment distortion; for this reason it holds a key role in active labour market policies (ALMPs) (Farooq \& Ofosu, 1992; Harman \& Brelade, 2000).

Within this context the European Union planned and developed its policy guidelines for VET under the influence of an international liberal trend which emphasised VET benefits. Moreover, adapting to the aforementioned changes, the EU initiatives were gradually extended towards a VET which would not only contribute to the development of national economies, but also become proactively involved in the member states societal concerns.

Although the idea of a unified Europe projected an economic orientation since its start, issues of employment were explicitly and directly addressed for the first time in the Amsterdam Treaty. Employment is seen as a "matter of common concern" that should be dealt with through coordinated actions (Treaty of Amsterdam, 1997, Title VIII, article 126). Also the aim of high employment rates should be served by formulating and implementing common policies and practices (Treaty of Amsterdam, 1997, Title VIII, article 127). Thus, the notion of the European Employment Strategy (EES) (Treaty of Amsterdam, 1997, Title VIII, article 125) was established carrying both an economic and a social dimension.

The EES was updated at the European Councils at Lisbon and Barcelona (Barcelona European Council, 2002; Lisbon European Council, 2000) and set concrete goals for the next decade regarding the main factors of employment conditions, such as employment participation and education/training achievements (Note 2). The EU focused on creating initiatives in a wide range of Active Labour Market Policies (ALMPs) that varied from jobs creation (either directly in the public sector or by subsidising ones in the private sector) to assistance for job search and training to enable educational and work mobility. 
For a long period of time EU policies on vocational education and training maintained a supplementary character aiming mainly at facilitating the productive processes in the member states. This attitude began to change when the ongoing developments showed broad transformations in the labour market conditions. The impact of the economic crisis on member states and societies made the discussions regarding EU initiatives to deploy a new VET role and dynamics, more attractive. In the next few years the anticipated technological and organisational advancement are expected to be accompanied by an increase in demand for high and middle level qualified labour force (Cedefop, 2008, 2009). The need for VET systems to be prepared to accomplish their role effectively, on time and with a long-term vision, made their reorganisation necessary.

Within this context the 'EU 2020 Strategy' (European Commission, 2010a, 2010b) has become the core of Europe's mobilisation for the promotion of EU and member states socioeconomic development on the basis of three pillars:

- Smart growth, through the promotion of knowledge, innovation and learning and digital society.

- Sustainable growth, with a production model which both utilises resources efficiently and increases competitiveness.

- Inclusive growth, by increasing employment and specialisation and combating poverty.

Two of the 'Europe 2020 Strategy' targets (Note 3) should be especially distinguished. The first one refers to employment and aims at achieving an employment rate of $75 \%$ on average for Europe by 2020 . The second one refers to education and projects the need for the decrease of early school leavers to less than $10 \%$ and for the increase of university or other equivalent education graduates to $40 \%$ of young people at least (Europe 2020 targets). Within this framework (Note 4), the importance of investment on human capital acquired a new meaning (European Commission, 2011c, p. 2). For this reason, the Commission-in its Communication that referred to the next Multiannual Financial Framework 2014 (European Commission, 2011b, Part I)-proposed the extension of the EU education and training programmes in order to improve skills and combat the high levels of youth unemployment; in this context, $€ 15$.2bn will be allocated over the period 2014-2020 to a single integrated programme on Education, Training, Youth and Sport (European Commission, 2011b, Part I, p. 25).

In January 2011, the European Commission (2011a) released its first 'Annual Growth Survey' (AGS) which by setting ten priorities attempts to create a new system that aspires to support national governments to coordinate their efforts against the economic challenges of the present. The AGS not only introduces actions which are essential to strengthen the short-term recovery, but also intends to enable Europe to keep pace with its main competitors and to be prepared for the 'Europe 2020' objectives.

\subsection{Aspects of Unemployment in the European Union}

Unemployment is one of the most dangerous problems in the European Union, because it is not confined only to economic implications for individuals and states, but also extends to social consequences.

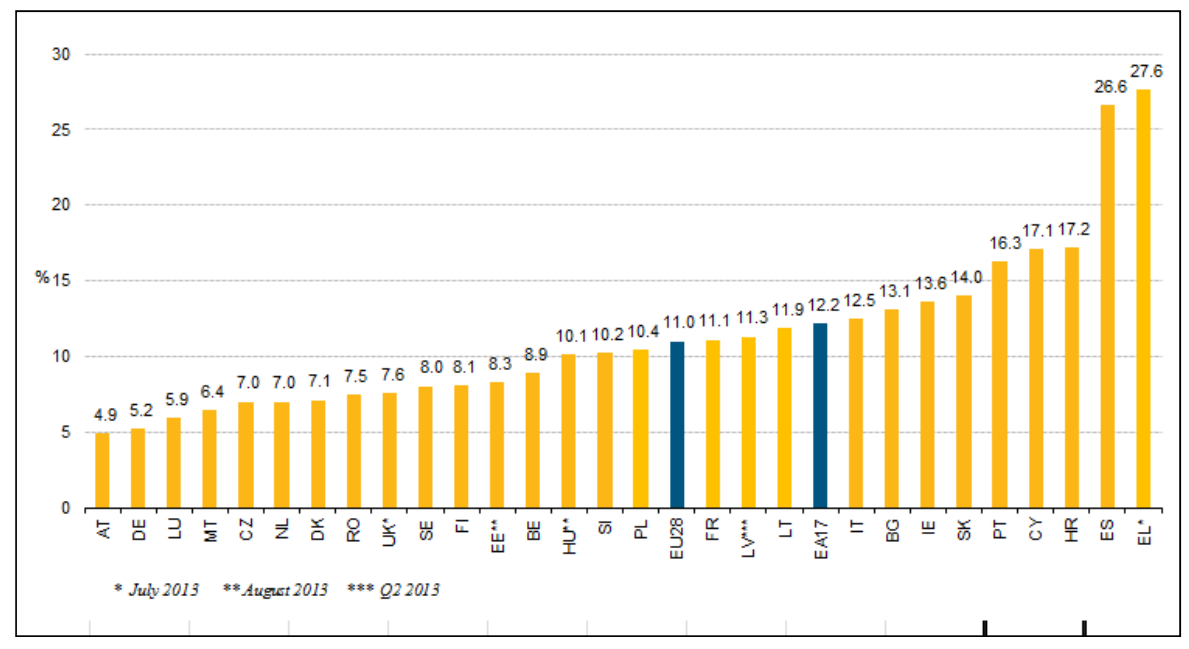

Source: Eurostat (une_rt_m)

Figure 1. Unemployment rates, seasonally adjusted, September 2013 (\%) 
Persisting high unemployment rates (Eurostat, 2013) especially in countries with severely challenged economies, such as Greece (27.6\%), Spain (26.6\%), Cyprus (17.1\%), Portugal (16.3\%) and Ireland (12.6\%), are indicative of it constituting a long-term potential threat for other European countries that indirectly experience the consequences of the global financial crisis (Figure 1).

The prospects are more pessimistic for the long-term unemployed. Lack of professional opportunities, skills mismatches or even erosion may lead to social exclusion and poverty, acceptance of unstable working conditions in terms of payment, social security and working hours (International Labour Organization, 2013). In addition, the loss of valuable human capital results in economic recession and undermines the collective social welfare (Ahn, García, \& Jimeno, 2004).

\begin{tabular}{|c|c|c|}
\hline \multicolumn{3}{|c|}{ EU-28 young population aged 15-24 } \\
\hline & \multicolumn{1}{|c|}{57.5 million persons } \\
\hline Employed & Unempl & Economically inactive \\
18.8 million & $5.6 \mathrm{~m}$ & 33.0 million \\
\hline Labour force & Not in the labour force \\
\hline
\end{tabular}

Source: Eurostat

Figure 2. Employment status of young people aged 15-24 in the EU

Undoubtedly, young people are the most severely hit by the crisis (Figure 2); especially those who are not in employment, education and training (NEETs) are at the most adverse position (Eurofound, 2012). In a globalized environment which experiences an incessant technological change young people face serious skills mismatches and, for this reason, enter the labour market with greater difficulty, are hired to non-secure, temporary jobs, enjoy lower wages and limited social security or become unemployed more often compared with elder employees. Finally, although youth unemployment is justified to cause great concern, the efficiency of the various adopted solutions remains largely unassessed and ambiguous (Görlich, Stepanok, \& Al-Hussami, 2013).

The dramatic increase of NEETs (Note 5) led the EU to launch new initiatives in an attempt to confront the unfavourable prospects for young people; VET institutional transformations are expected to exercise a significant role towards this end. Almost $14 \mathrm{~m}$ NEETs (Table 1) encumber European economy with a cost of $€ 153 \mathrm{~m}$ euros, which is equivalent to $1.2 \%$ of EU GDP (Eurofound, 2012, p. 2). The consequences for member states are profound (Eurofound, 2012). NEETs are gradually decreasing only in four countries (Austria, Germany, Luxembourg and Sweden), but they show a double-digit increase in most other countries (Table 1). The impact should not be calculated strictly on economic grounds as a percentage of the GDP, but as factor of serious social unrest especially.

Any national attempt for economic recovery is hindered by the persisting financial woes (Table 1; Figure 3); Greece-with a $54.7 \%$ increase of NEETs-has a burden of $€ 7.1 \mathrm{bn}$, for Spain-with a $34.4 \%$ increase of NEETsthe cost is $€ 15.7 \mathrm{bn}$ and for Ireland-with a $37.5 \%$ increase of NEETs- $€ 4.3 \mathrm{bn}$, while Portugal has a $17.7 \%$ and Cyprus a $34.9 \%$ increase of NEETs (Eurofound, 2012; The Guardian, 2012).

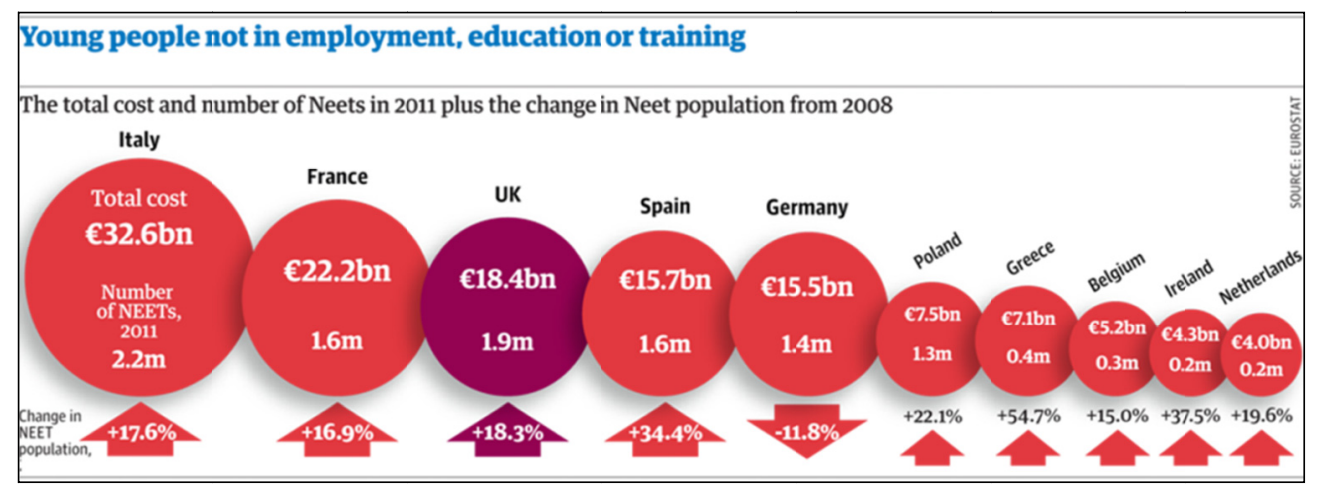

Figure 3. NEETs in the EU; numbers and costs (Note 6) 
Table 1. Not in education, employment or training in Europe

\begin{tabular}{|c|c|c|c|c|c|c|}
\hline Country & $\begin{array}{c}\% \text { increase } \\
\text { in NEET } \\
\text { population } \\
2008 \text { to } 2011\end{array}$ & $\begin{array}{l}\text { Total cost } \\
2011 \text { ( } € b n)\end{array}$ & $\begin{array}{c}\% \text { of } \\
\text { GDP } \\
(2011)\end{array}$ & $\begin{array}{l}\% \text { of } \\
\text { GDP } \\
(2008)\end{array}$ & $\begin{array}{c}\text { \% of NEETs, } \\
\text { aged 15-29 } \\
(2007)\end{array}$ & $\begin{array}{c}\text { \% of NEETs, } \\
\text { aged 15-29 } \\
(2011)\end{array}$ \\
\hline Austria & -4.7 & 3.17 & 1.06 & 1.08 & 8.9 & 8.2 \\
\hline Belgium & 15 & 5.21 & 1.42 & 1.17 & 13 & 13.8 \\
\hline Bulgaria & 33 & 1.27 & 3.31 & 2.36 & 20.3 & 24.6 \\
\hline Cyprus & 34.9 & 0.42 & 2.39 & 1.65 & 10.3 & 14.7 \\
\hline Czech Republic & 14 & 1.8 & 1.16 & 0.97 & 11.6 & 12.2 \\
\hline Denmark & 52 & 1.29 & 0.54 & 0.33 & 5.3 & 7.6 \\
\hline Estonia & 29.6 & 0.31 & 1.93 & 1.29 & 11.5 & 14.9 \\
\hline Finland & 12.4 & 2.02 & 1.07 & 0.88 & 8.4 & 10 \\
\hline France & 16.9 & 22.18 & 1.11 & 0.92 & 12.6 & 14.5 \\
\hline Germany & -11.8 & 15.46 & 0.6 & 0.66 & 11.6 & 9.7 \\
\hline Greece & 54.7 & 7.07 & 3.28 & 1.74 & 15.5 & 23.2 \\
\hline Hungary & 12 & 2.13 & 2.12 & 1.55 & 15.3 & 17.7 \\
\hline Ireland & 37.5 & 4.33 & 2.77 & 1.74 & 11.9 & 22 \\
\hline Italy & 17.6 & 32.61 & 2.06 & 1.6 & 18.9 & 22.7 \\
\hline Latvia & 41.7 & 0.54 & 2.67 & 1.47 & 13.7 & 18.7 \\
\hline Lithuania & 26.7 & 0.33 & 1.07 & 0.69 & 9.7 & 15.2 \\
\hline Luxembourg & -28.3 & 0.1 & 0.23 & 0.31 & 7.3 & 6.6 \\
\hline Netherlands & 19.6 & 3.96 & 0.66 & 0.52 & 4.9 & 5.5 \\
\hline Poland & 22.1 & 7.54 & 2.04 & 1.48 & 14.4 & 15.5 \\
\hline Portugal & 17.7 & 2.68 & 1.57 & 1.24 & 12.7 & 14 \\
\hline Romania & 44.7 & 2.1 & 1.54 & 0.85 & 14.8 & 19.1 \\
\hline Slovakia & 22.2 & 0.69 & 0.99 & 0.8 & 16.9 & 18.7 \\
\hline Slovenia & 25.3 & 0.47 & 1.31 & 0.92 & 8.2 & 9.4 \\
\hline Spain & 34.4 & 15.74 & 1.47 & 0.99 & 13.1 & 21.1 \\
\hline Sweden & -2.5 & 1.26 & 0.33 & 0.36 & 7.9 & 7.8 \\
\hline United Kingdom & 18.3 & 18.35 & 1.05 & 0.75 & 12.9 & 15.5 \\
\hline European Union & 17.6 & 153.01 & 1.21 & 0.96 & 13.2 & 15.4 \\
\hline
\end{tabular}

Source: Eurostat

\subsection{A New Role for Vocational Education and Training}

Under the pressure of the economic crisis, vocational education and training has acquired special importance and an advanced policy framework regarding VET has been promoted by the EU. Such a transformation was considered essential because of the new forms of needs and the pressures exercised on the European governance structure. It could certainly be argued that this framework shows that previous European initiatives have been 
further elaborated. In the EU half the student population on average already attends vocational education (49.9\% for 2010), but in the long-term VET remains less attractive and fewer students attend a vocational stream in their education in many countries (Table 2). This can be attributed to its alleged failure to satisfy the anticipations of the students, their families and the labour market regarding its effectiveness in realising their professional prospects (European Commission - Eurobarometer, 2011). Nevertheless, Europeans are expected to be more inclined towards this type of education considering it far more attractive when choosing their educational orientation (European Commission - Eurobarometer, 2011).

Table 2. Student participation with vocational orientation in upper secondary education (ISCED-3) - (\%)

\begin{tabular}{|c|c|c|c|c|c|c|c|}
\hline Country & 2002 & 2004 & 2007 & 2008 & 2009 & 2010 & 2011 \\
\hline EU-27 & 57.6 & 60.6 & 51.5 & 50.3 & 49.6 & 49.9 & $:$ \\
\hline Euroarea-17 & 49.6 & 57.7 & 54.3 & 54.5 & 53.6 & 53.7 & $:$ \\
\hline Belgium & 69.7 & 68.2 & 69.6 & 72.9 & 72.8 & 73.0 & 72.8 \\
\hline Bulgaria & 55.5 & 55.2 & 53.4 & 52.3 & 51.8 & 52.2 & 52.2 \\
\hline Czech Republic & 80.2 & 79.4 & 75.3 & 74.2 & 73.3 & 73.1 & 73.0 \\
\hline Denmark & 53.0 & 46.8 & 47.7 & 48.0 & 47.3 & 46.5 & : \\
\hline Germany & 63.0 & 61.2 & 57.4 & 57.5 & 53.2 & 51.5 & 48.6 \\
\hline Estonia & 31.5 & 29.9 & 31.3 & 32.0 & 33.0 & 34.2 & $:$ \\
\hline Ireland & : & 33.5 & 33.5 & 33.9 & 34.4 & 37.5 & 34.0 \\
\hline Greece & 40.0 & 34.0 & 31.7 & 30.9 & $:$ & 30.7 & $:$ \\
\hline Spain & 38.0 & 38.7 & 43.4 & 43.8 & 42.9 & 44.6 & 45.3 \\
\hline France & 56.3 & 56.5 & 43.8 & 44.2 & 44.2 & 44.3 & 44.6 \\
\hline Italy & 26.8 & 62.8 & 59.8 & 59.4 & 59.0 & 60.0 & : \\
\hline Cyprus & 13.8 & 13.4 & 13.0 & 12.6 & 12.8 & 13.2 & $:$ \\
\hline Latvia & 39.1 & 36.8 & 34.4 & 34.8 & 36.1 & 36.0 & 37.8 \\
\hline Lithuania & 28.2 & 24.8 & 26.4 & 26.3 & 26.4 & 27.7 & 28.4 \\
\hline Luxembourg & 64.0 & 63.9 & 62.3 & 62.1 & 61.3 & 61.5 & : \\
\hline Hungary & 12.8 & 23.7 & 23.6 & 24.4 & 24.5 & 25.8 & 26.2 \\
\hline Malta & 32.8 & 55.0 & 48.5 & 50.1 & 58.1 & 49.3 & $:$ \\
\hline Netherlands & 69.2 & 69.1 & 67.6 & 67.1 & 67.1 & 67.0 & : \\
\hline Austria & 72.3 & 78.6 & 77.3 & 77.1 & 77.3 & 76.8 & 76.1 \\
\hline Poland & 60.9 & 49.5 & 44.3 & 46.2 & 47.2 & 48.2 & 48.3 \\
\hline Portugal & 28.8 & 28.5 & 31.6 & 30.7 & 38.4 & 38.8 & : \\
\hline Romania & 64.0 & 64.8 & 64.9 & 64.8 & 63.7 & 63.8 & 63.1 \\
\hline Slovenia & 70.3 & 68.6 & 64.9 & 64.5 & 64.3 & 64.6 & 65.4 \\
\hline Slovakia & 76.4 & 74.1 & 73.2 & 72.3 & 71.6 & 71.3 & 70.9 \\
\hline Finland & 57.2 & 60.1 & 66.7 & 67.9 & 68.8 & 69.7 & 69.6 \\
\hline Sweden & 49.6 & 53.4 & 57.1 & 56.8 & 56.4 & 56.1 & 56.3 \\
\hline United Kingdom & 72.1 & 71.5 & 41.4 & 31.4 & 30.5 & 32.1 & 36.0 \\
\hline
\end{tabular}

Source: Eurobarometer

In light of the current socioeconomic circumstances the dynamics of the entrepreneurial culture in member states have also drawn the attention. Until fairly recently any entrepreneurial initiative was mainly embarked on due to 
personal ambition largely depending on the level of corporate mentality and the presence of the appropriate conditions (Shane, Locke, \& Collins, 2003). Today, a new role for VET has emerged: not only is it called upon to support a new vision for future economic development, but also to prepare individuals' mentality and expertise for them either to implement a new model of production as entrepreneurs or to efficiently serve it as employees.

The speed of integration of entrepreneurship varies in the different member states depending mainly on structural conditions. Adverse economic circumstances forced the EU to incorporate an organised model of fostering an entrepreneurial culture in the national educational systems (EACEA-Eurydice, 2012). Nevertheless, the case of enhancing the entrepreneurial spirit through educational activities as projected by new EU orientations and actions shows that the opportunity for innovative interventions is still at development stage. Relevant strategies or initiatives have not yet been activated in a large part of Europe (Figure 4).

So far, in some countries such initiatives have been assumed only by private organisations and institutions in cooperation with the business world; they aim for students' familiarisation to the theory and practice of corporate ventures (Boutsiouki, 2012) providing knowledge and organising contests (Note 7). Surprisingly, in the case of VET there is not much difference from the situation in general education, although stronger industry ties are expected to develop. The formation of a powerful entrepreneurial mindset in young people is delayed. Consequently, they remain aloof from entrepreneurial initiatives and their potential involvement in such ventures is hindered (EACEA-Eurydice, 2012).

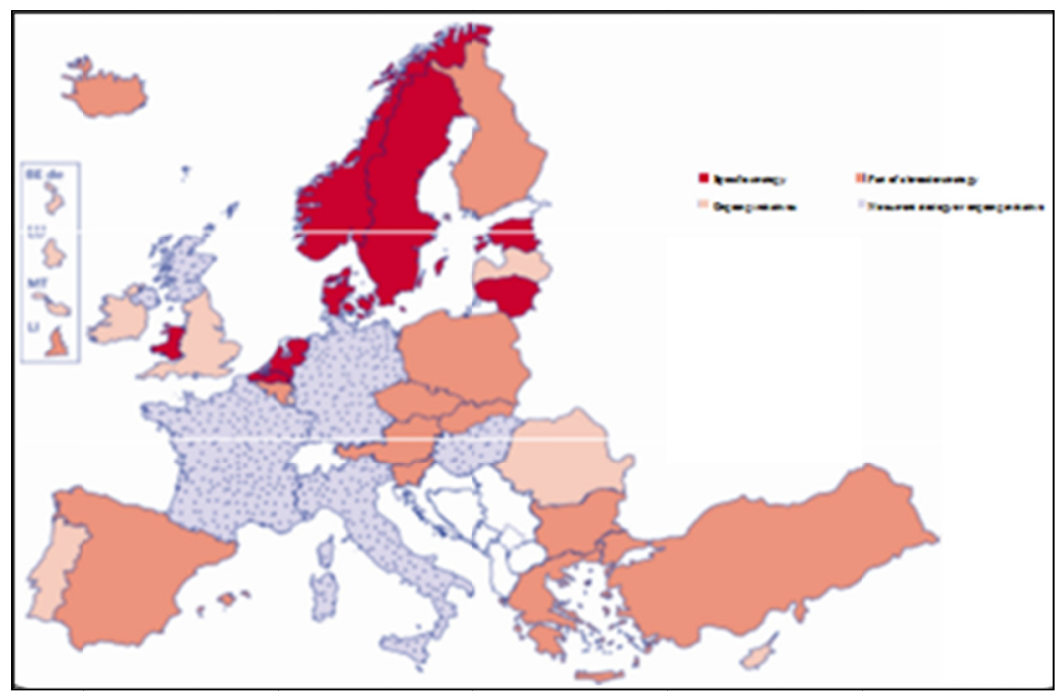

\begin{tabular}{|ll|}
\hline$\square$ & specific strategy \\
$\square$ & part of a broader strategy \\
$\square \quad$ & ongoing initiatives \\
& no current strategy or ongoing initiative
\end{tabular}

Source: EACEA-Eurydice, 2012, p. 8

Figure 4. National strategies and initiatives to the implementation of entrepreneurship education (general education - ISCED 1-3) [2011-2012]

\section{Challenging Transitions: EU Legislative Interventions and Tools of Policy Implementation}

\subsection{Towards a New Strategy for VET}

The aspiring transition of the EU towards a "competitive and dynamic knowledge-based economy ... capable of sustainable economic growth with more and better jobs and greater social cohesion" (Lisbon European Council, 2000) introduced new challenges to the development of human resources. The transition from education to work as well as the (horizontal or vertical) mobility between different work positions or educational opportunities constitutes a crucial structural challenge for the European Union. As the conditions are aggravated by the financial crisis, limited participation in VET activities seems to further impede any positive prospects. For this 
reason individuals should be offered stronger incentives and proper assistance to participate in vocational education/training and in activities closely related to their progression to employment. During the last decade the European Union has undertaken a series of significant legislative initiatives in an effort to build a favourable environment for such challenging transitions.

The Copenhagen Declaration occupies a key position in European policies regarding education and training. It highlighted the importance of strategies for lifelong learning and mobility that reinforce employability, active citizenship, social inclusion and personal development (Council of the European Union, 2002a, 2002b). Hence the launch of the European strategy for the enhanced cooperation in VET is hereinafter called the "Copenhagen process' (Council of the European Union, 2002b, 2002c). The policy enforcement model that was introduced included three dimensions to be implemented by 2010:

o A political dimension aimed at the promotion of defining common European targets and reforming national VET systems.

- An operational dimension aimed at the development of common European frameworks and tools for the mutual recognition and validation of competences and qualifications, in order to increase their transparency and quality and facilitate mobility.

- An organisational dimension aimed at the cooperation for the promotion of reciprocal learning at European level through the incorporation of all the authoritative bodies involved at national level. This was expected to facilitate information, orientation and counseling on VET and to capitalize any investment creating economies of scale.

The priorities of enhanced European cooperation on VET were further specified by the Maastricht Communiqué (2004). It projected the need to develop common means and benchmarks for the reform of VET systems, while at the same time it underlined the urgency to increase public and private investment and to invest European Funds resources (ESF, ERDF) more efficiently. The inclusion of individuals and groups at a disadvantage in VET systems also became necessary. Finally, the issue of intensifying VET regarding methodology (Note 8) and a flexible and open framework (Note 9) was also put forward.

Besides the aim of improving the organisational structure of VET systems, the necessity to improve the VET prestige and attractiveness became more apparent in the Helsinki Communiqué (2006). Common tools and the use of fixed and comparable data and indicators for VET should be introduced in order to achieve the European integration in education. For this reason in the following years the European Union elaborated on the development of new tools especially designed to enable the comparability of knowledge, skills and competences, as well as qualifications earned in different educational systems and labour markets. Thus, the aspired permeability between the last two and the mobility of individuals as recipients or providers of lifelong learning services would become attainable.

\subsection{Europass}

The new policy orientations resulted in the Europass (European Parliament and the Council, 2004) setting a common European framework of reference for the validation of a personal coordinated portfolio (Note 10). It was designed to facilitate educational and employment mobility by establishing a system that successfully reflects what a person has achieved in terms of qualifications, knowledge and competences throughout the European area. Nevertheless, it suffers from some disadvantages. In particular, it cannot accurately depict existing differences in labour market cultures which influence the employers' expectations from candidates. Similarly for personality traits, although they are perceived as very significant in the recruitment process in most labour markets, it cannot accurately describe transferable skills to potential employers or capture what individuals have actually gained from their life experiences. The rather long format of the Europass CV is another significant disadvantage; it requires employers or recruitment officials to read it at its length, so as to form a full evaluation of the candidate. On the contrary, in some countries (ex. in the United Kingdom) the recruitment process is largely based on the first-page-impression imprinting as much information as possible. Despite a few imperfections, the Europass mechanism came to assist the activity of Ploteus (Ploteus portal), a website which was designed to operate as a search tool for education and vocational training opportunities in EU member states. Both the Europass and Ploteus were created as policy instruments that would support future arrangements regarding the official recognition of professional qualifications within the European area.

\subsection{European Qualifications Framework - EQF}

The European Qualifications Framework - EQF (European Parliament and the Council, 2008) shaped a common reference framework based on -formal, non-formal or informal- learning outcomes. It is characterised by a 
detailed structure with eight distinct levels of learning outcomes ('knowledge', 'skills' and 'competences') and its terminology is applicable to all learning environments, regardless of the system a particular qualification was awarded by (European Parliament and the Council, 2008, Annex I). It gives the ability to member states, educational organisations, employers and citizens to compare qualifications attributed by different education and training systems. As a result, member states entered into a procedure to form their own national qualification frameworks or to transform existing ones accordingly as a necessary step towards an integrated European labour market.

As soon as the establishment of national qualifications frameworks is completed, every qualification issued by learning institutions in the EU will automatically refer to one of the aforementioned levels. Such a detailed structure provides many advantages. On the one hand, the EQF ensures the transparency and, thus, the fair comparability of competences and qualifications in the labour market. On the other hand, the fact that it focuses on someone's overall learning, enables the evaluation and recognition of learning acquired outside formal education and training institutions; therefore the concept of lifelong learning as a continuous process is reinforced. In addition, the ease of transfer and recognition of qualifications and competences in the European area facilitates educational and professional mobility for citizens, when such opportunities eventually arise. Furthermore, the implementation of the EQF principles in all member states contributes to the recruitment processes for employers, thus ameliorating conditions for transitions (from education and training to work and vice versa). Interesting advantages are also projected regarding the quality of education and training services because of the ability to compare learning outcomes between different member states and to gain valuable experience from good practices. Finally, the application of EQF principles will certainly benefit the EU employment strategy and its transition initiatives, because the establishment of qualitative assessment practices and the recognition of different forms of learning would link education and training to the labour market and civil society in a more proactive way.

\subsection{European Credit System for Vocational Education and Training - ECVET}

The achievement of economic growth largely depends on effective professional training which can be offered in different educational environments. The European Credit System for Vocational Education and Training ECVET (European Parliament and the Council, 2009a) serves as a policy instrument that is applied on learning outcomes obtained in different educational environments and transferred, recognised and accumulated in order that a professional qualification can be obtained (Note 11). Its implementation defines the recognition of the individuals' training, skills and knowledge in a country other than the one awarding them. As the transfer of credits between different qualifications systems becomes easier and transparent, educational and professional mobility within the EU and lifelong access to knowledge are further promoted; at the same time interesting aspects of the issue arise (UNICA et al., 2010; De Lavigne, 2011).

\subsection{European Quality Assurance in Vocational Education and Training - ECVET}

Finally, the European Quality Assurance in Vocational Education and Training - EQAVET (European Parliament and the Council, 2009b) was designed in order to provide to the authorities of member states common tools for quality management in VET. It aims at supporting their efforts to evaluate, to improve and to develop the quality of their VET systems through common and, therefore, comparable practices; eventually, this would allow for the modernisation of the learning environments in the EU and would make VET mobility accessible and effective.

\subsection{Enhancement of a New Vision}

The above mentioned policy transformations regarding VET were followed by the Bruges Communique on enhanced European cooperation in vocational education and training. The long-term policy agenda included a renewed action framework and incorporated a new overall vision for VET for the decade 2011-2020. First of all, it supported the idea that VET should become attractive for all. Such an accomplishment calls for high skilled trainers, innovative learning, high quality infrastructure, different paths to continuous education and training and strong ties to the labour market. This aim entailed additional institutional interventions for both initial and continuous VET systems. Initial VET should ensure high quality studies, so that basic competences and concrete vocational qualifications are not only provided to, but also valued by students, their parents and the society as equally attractive to those provided by general education. Similarly, continuous VET should be flexible, accessible and career-oriented. It should also be addressed to employees, employers and independent entrepreneurs or unemployed individuals who aim at upgrading their skills and proceeding to a change in career. Secondly, the new VET agenda encouraged the development of flexible VET systems on the basis of learning outcomes. Through these means, it is expected to facilitate the transferability of learning outcomes between 
different subsystems of education/training and the certification of non-formal and informal learning. Thirdly, it emphasised the formation of a European education and training area that ensures the transparency of certification of qualifications; thus, the transfer of learning outcomes, the recognition of qualifications and competences, and, consequently, the transnational mobility for trainees and trainers can be achieved. Finally, easier access to high quality information, orientation and counseling services would be better supported by the formation of a coherent network for European citizens to manage their learning, career options and decisions (Bruges Communiqué, 2010).

\section{New Policy Initiatives}

EU policy is not limited only to the creation of new tools, whose implementation would greatly benefit employment prospects; it also aspires to ignite new initiatives that could effectively increase employment and education/training participation, especially for young people- an age group extremely vulnerable and exposed to the consequences of the crisis. Such initiatives would not only focus on providing the appropriate environment for learning and employment opportunities, but would also exploit efficiently the policy framework and instruments already provided by previous $\mathrm{EU}$ institutional interventions.

In 2010 the 'Youth on the Move' initiative (European Commission, 2010c) set out as a part of the 'Europe 2020 strategy' and focused on employment, education and training issues especially for young people. Consecutively, in December 2012 a new framework of action was formed under the title 'Youth Employment Package' (European Commission, 2012) in an effort to find ways to promote youth employment.

A European Council recommendation named 'Youth Guarantee' (Council of the European Union, 2013) derived from this new framework. This initiative takes advantage of relevant precedents in certain European countries regarding young people either unemployed or at risk of unemployment (Note 12); such guarantees were introduced in order to ensure that opportunities for a job or an educational/training offer were available for their young cohorts, whereas in some cases they impose a duty of meeting the needs of young people on providers (European Commission, 2011e, pp. 17-18). Among others, the EU Youth Guarantee provides for young individuals 25 years old or younger to "receive an offer for employment, education, apprenticeship or work experience within 4 months from the day they become unemployed or graduate from formal education". Measures associated with the realisation of the aforementioned objectives are to be implemented through the 'Youth Employment Initiative' (European Commission, 2013), which mainly focuses on NEETs and on the regions where youth unemployment is over $25 \%$. This initiative will attempt to facilitate youth transition to the labour market with a budget of $€$ 6bn for the period 2014-2020.

Besides the institutional interventions that were analysed above, the revised 'Erasmus for all' (European Commission, 2011d, Vol. 2) has been activated in 2014 as an all-inclusive programme. It incorporates every programme in the policy areas of education, training, youth and sports that until now was managed independently in its operational and financial dimension; the basic aim is to improve cooperation, to encourage mobility and to increase extroversion at European and international level. There are aspirations that such a mechanism will ensure a combined system of actions which can mutually cooperate or complement each other, can be easily managed and become more widely acknowledged.

\section{Discussion and Conclusions}

European integration is a long-term and laborious procedure founded on and galvanised by the benevolent cooperation of national authorities, social partners and citizens. At the same time, its achievement goes through a series of mutually complementing strategies and policy practices. The quality of their coordination defines whether the vision of European integration can be accomplished through internal forces on equal terms for all. Alternatively, externally imposed developments would only result in inequality and socially detached outcomes.

During the last decade the EU has undertaken a number of initiatives aiming at enhancing its integration and growth-at macro level-and the mobility of Europeans in search of educational or professional experiences/opportunities-at mid- and short-level. The reorganisation and the quality of VET became principal issues of policy discussions, because of its capability to influence a broad range of European policies including economic and social policy. The persistence of certain deficiencies should not be overlooked; the depreciation and marginalisation of the labour force because of its inability to adapt to change; its difficulty to participate in a new model of production; unemployment; the potential deprivation of valuable human resources due to increased mobility towards other countries. Therefore, VET should constitute a major part of the recovery strategic plan. The quantitative and qualitative comparability of knowledge, skills and competences is a fundamental prerequisite for the realisation of educational or professional opportunities. The achievement of this 
goal benefits individuals and the EU to effectively exploit the potential and maximise the efficiency of human resources.

This paper presented the main legislative interventions and institutional tools through which the European Union pursues the reorganisation of VET systems in terms of operation and quality for educational or employment purposes. These EU initiatives aspire to increase the opportunities of individuals to develop their competencies and to broaden their knowledge and creative spirit by accessing multiple educational environments within the common European area. Such interventions are expected to increase their access to mobility opportunities at national and European level and to overcome problems regarding the recognition and accumulation of their qualifications and previous professional experience. The importance attached to the aforementioned initiatives is not related only to the improvement of their socioeconomic prospects, but also to the ability of member states to ignite development actions and economic growth.

It can be argued that the introduced legislative initiatives and policy measures are enough and there is no need for new policy interventions. In fact, there is great importance for the EU and member states' authorities to actively focus on the existing measures in an attempt to achieve their implementation, to increase their efficiency and to succeed in making them accessible to all, so that they effectively operate in favour of the European development.

Obstacles do exist. The significant mismatch between the labour market and the educational outcomes certainly exercises a negative impact on the ability of European countries to effectively develop and implement their national frameworks of reference mentioned in this paper. Also, labour market differences impede the formation of a 'common language' of understanding that would realise the transferability of knowledge, skills and competences as expressed through the individuals' educational and professional achievements. Undoubtedly, a creative communication between education and the labour market is advisable.

Although the key principles of the legislative regulations have been integrated by the member states, certain disadvantages in the implementation of mobility-enhancing interventions should be addressed. First of all, there has been a serious delay in the development and the actual implementation of the new provisions in most countries. Secondly, the dissemination of the new policies and practices is confined to only a small part of the actual recipients; many individuals, educators and employers in the EU lack the necessary knowledge, familiarisation and capability to exploit the new policy instruments to their advantage. Therefore, the new initiatives need to be promoted more proactively in order to be accessible by broader groups of people, to be integrated in the national policies and to become the foundations of the respective national frameworks and implementation tools.

Besides addressing the weaknesses of the initiatives that have already been introduced, the investment on additional implementation-enhancing actions should be included. The dissemination of the new policy initiatives and measures should be promoted through the exploitation of effective practices of information and guidance. At the same time, networking should be enhanced in order to facilitate mobility between different educational or professional establishments.

Undeniably, the promotion of new and ambitious policy measures in a European Union severely hit by the ongoing fiscal crisis entails several difficulties of a different nature. Most European countries are obliged to reassess their priorities under the pressure of augmented debts and deficits. As a result, national governments have limited capacity to proceed with the implementation of approved initiatives and, therefore, they exercise restrictive policies. A sustainable solution would be to invest in exploiting the potential of already existing policy measures and mechanisms further, strengthening the member states' cooperation and cohesion regarding these areas of interest until the socioeconomic circumstances are improved.

Concluding, there are two major questions that need to be answered.

First, how do the authoritative bodies in the EU and the member states intend to slow down the recession caused by the economic crisis and to ignite growth in order to confront the increasing global economic competition? Unfortunately, until now the EU has shown an impressive delay in implementing many of the above mentioned initiatives and, therefore, in expressing a more dynamic attitude and decisiveness.

Secondly, which are the initiatives through which the EU intends to react to the constantly expanding social demand for knowledge, the mass participation of citizens in learning activities, the quality upgrade of the labour force and -potentially (?)- the solution of issues related to employment irregularities? 
For obvious reasons the first question cannot be answered on strictly academic grounds. Nevertheless, what is left is to upgrade the quality of the answers to the second question by focusing on the existing policy institutions and mechanisms in anticipation of a positive impact on the potential answers to the first question.

\section{References}

Ahn, N., García, J. R., \& Jimeno, J. F. (2004). The Impact of Unemployment on Individual Well-Being in the EU. ENEPRI Working Paper No. 29 (July 2004).

Allais, S. (2010). The implementation and Impact of National Qualifications Frameworks: Report of a study in 16 countries. Geneva: ILO. Retrieved January 28, 2014, from http://www.ilo.org/wcmsp5/groups/public /---ed_emp/---ifp_skills/documents/meetingdocument/wcms_126589.pdf

Anderson, D. (2009). Productivism and Ecologism: Changing Dis/courses in TVET. In J. Fien, R. Maclean, \& M. G. Park (Eds.), Work, Learning and Sustainable Development: Opportunities and Challenges (pp. 35-57). UNESCO-UNEVOC Book Series, Technical and Vocational Education and Training: Issues, Concerns and Prospects, V. 8. Netherlands: Springer. http://dx.doi.org/10.1007/978-1-4020-8194-1_3

Barcelona European Council. (2002, March15-16). Presidency conclusions. Retrieved October 15, 2013, from http://www.consilium.europa.eu/uedocs/cms_data/docs/pressdata/en/ec/71025.pdf

Becker, G. (1994). Human Capital: A Theoretical and Empirical Analysis with Special Reference to Education (3rd ed.). New York: Columbia University Press for National Bureau of Economic Research.

Becker, G. (1995). Human Capital and Poverty Alleviation. Human Resources Development and Operations Policy. HRDWP 52.

Boutsiouki, S. (2012). Well Begun is Half Done: Preparing Citizens who Care. 2nd International Multidisciplinary Conference organised by the PIDOP Consortium in collaboration with the Centre for Research on Nationalism, Ethnicity and Multiculturalism (CRONEM) «Political and Civic Participation». Surrey, United Kingdom: PIDOP. Retrieved from http://www.surrey.ac.uk/cronem/newsandevents /conferences/pidop_papers_and_presentations.htm

Bruges Communiqué. (2010). Communiqué of the European Ministers for Vocational Education and Training, the European Social Partners and the European Commission. Meeting in Bruges on 7 December 2010 to review the strategic approach and priorities of the Copenhagen process for 2011-2020. Retrieved October 23, 2013, from http://ec.europa.eu/education/lifelong-learning-policy/doc/vocational/bruges_en.pdf

Cedefop. (2008). Future skill needs in Europe. Medium-term forecast: Synthesis report. Luxembourg: Publications Office.

Cedefop. (2009). Future skill supply in Europe. Medium-term forecast up to 2020: Synthesis report. Luxembourg: Publications Office.

Cedefop. (2013). Benefits of Vocational Education and Training in Europe for People, Organisations and Countries. Luxembourg: Publications Office of the European Union. http://dx.doi.org/10.2801/18161

Cedefop. (2014). Macroeconomic benefits of vocational education and training. Luxembourg: Publications Office of the European Union. http://dx.doi.org/10.2801/32921

Côté, J. E. (2005). Identity capital, social capital, and the wider benefits of learning: Generating resources facilitative of social cohesion. London Review of Education, Vol. 3, No 3, 221-237. http://dx.doi.org $/ 10.1080 / 14748460500372382$

Council of the European Union. (2002a). Council Resolution of 27 June 2002 on lifelong learning [OJ 2002/C $163 / 01$ of 9.7.2002].

Council of the European Union. (2002b). Declaration of the European Ministers of Vocational Education and Training, and the European Commission. Convened in Copenhagen on 29 and 30 November 2002, on enhanced European cooperation in vocational education and training - 'The Copenhagen Declaration'.

Council of the European Union. (2002c). Council Resolution of 19 December 2002 on the promotion of enhanced European cooperation in vocational education and training [OJ 2003/C 13/02 of 18.1.2003].

Council of the European Union. (2013). Recommendation of 22 April 2013 on establishing a Youth Guarantee [OJ C 120/1 of 26.4.2013].

Crossley, M., \& Jarvis, P. (2001). Context matters. Comparative Education 37, 405-408. http://dx.doi.org/10.1080/03050060120091210 
Crouch, C., Finegold, D. \& Sako, M. (1999). Are Skills the Answer? The Political Economy of Skill Creation in Advanced Industrial Countries. Oxford: OUP. http://dx.doi.org/10.1093/acprof:oso /9780198294382.001.0001

De Lavigne, R. (2011). ECTS and ECVET: Comparisons and Contrasts. Project Title: Sectoral Qualifications Framework for Humanities \& Arts. Education and Culture DG, Lifelong Learning Programme, Tuning educational structures in Europe (October). Retrieved October 15, 2013, from http://www.unideusto.org/tuningeu/images/stories/HUMART/ECTS_and_ECVET_-_Comparisons_and_Co ntrasts.pdf

Durand-Drouhin, M., McKenzie, P., \& Sweet, R. (1998). Opening Pathways from Education to Work. The OECD Observer, Jan., 5-7.

EACEA-Eurydice. (2012). Entrepreneurship Education at School in Europe; National Strategies, Curricula and Learning Outcomes. Brussels: Eurydice.

Eurofound. (2012). NEETs - Young People Not in Employment, Education or Training: Characteristics, Costs and Policy Responses in Europe. Luxembourg: Publications Office of the European Union.

Europe 2020 Targets. (EU and member states). Retrieved October 20, 2013, from http://ec.europa.eu/europe2020/pdf/targets_en.pdf

European Commission - Eurobarometer. (2011). Attitudes towards Vocational Education and Training. Special Eurobarometer 369 (September 2011). Retrieved November 15, 2013, from http://ec.europa.eu/public _opinion/archives/ebs/ebs_369_en.pdf

European Commission. (2010a). Communication of 3 March 2010 from the Commission on Europe 2020; A strategy for smart, sustainable and inclusive growth COM (2010) 2020 final.

European Commission. (2010b). Proposal of 27 April 2010 for a Council Decision for the employment policies of the Member States - Part II of the Europe 2020 Integrated Guidelines \{SEC(2010) 488 final\}, $\operatorname{COM}(2010) 193$ final, 2010/0115 (NLE).

European Commission. (2010c). Communication of 15 September 2010 to the European Parliament, the Council, the European Economic and Social Committee and the Committee of the Regions - Youth on the Move; An initiative to unleash the potential of young people to achieve smart, sustainable and inclusive growth in the European Union COM(2010) 477 final \{SEC(2010) 1047\}.

European Commission. (2011a). Communication of 12 January 2011 from the Commission to the European Parliament, the Council, the European Economic and Social Committee of the Regions; Annual Growth Survey advancing the EU's comprehensive response to the crisis. COM (2011) 11 final. Retrieved November 15, 2013, from http://ec.europa.eu/europe2020/tools/monitoring/annual_growth_survey 2011/index_en.htm

European Commission. (2011b). Communication of 29 June 2011 from the Commission to the European Parliament, the Council, the European Economic and Social Committee and the Committee of the Regions on a Budget for Europe 2020 \{SEC(2011) 867 final\} \{SEC(2011) 868 final\}, COM(2011) 500 final, Part I.

European Commission. (2011c). Proposal of 23 November 2011 for a Regulation of the European Parliament and of the Council establishing 'Erasmus for all', The Union Programme for Education, Training, Youth and Sport (Text with EEA relevance) $\{\operatorname{SEC}(2011) 1402\}\{\operatorname{SEC}(2011) 1403\}, \operatorname{COM}(2011) 788$ final, 2011/0371 (COD), C7-0436/11.

European Commission. (2011d). Commission Staff Working Paper of 23 November 2011 on the Impact Assessment on Education and Training Actions (accompanying the document Proposal for a Regulation of the European Parliament and of the Council establishing a single Education, Training, Youth and Sport Programme for the Period 2014-2020 \{COM(2011) 788\} \{SEC(2011) 1403\}) SEC(2011) 1402 final, Volume 2.

European Commission. (2011e). European Employment Observatory Review - Youth employment measures 2010. Directorate General for Employment, Social Affairs and Inclusion (Unit C1). Luxembourg: Publications Office of the European Union.

European Commission. (2012). Communication of 5 December 2012 to the European Parliament, the Council, the European Economic and Social Committee and the Committee of the Regions - Moving Youth into Employment $\{\operatorname{SWD}(2012) 406$ final $\}, \operatorname{COM}(2012) 727$ final. 
European Commission. (2013). Communication of 12 March 2013 to the European Parliament, the Council, the European Economic and Social Committee of the Regions - Youth Employment Initiative COM(2013) 144 final.

European Parliament and the Council. (2004). Decision No. 2241/2004/EC of 15 December 2004 on a Single Community Framework for the Transparency of Qualifications and Competences (Europass) [OJ L 390/6 of 31.12.2004].

European Parliament and the Council. (2008). Recommendation of 23 April 2008 on the Establishment of the European Qualifications Framework for Lifelong Learning [OJ C 111/1 of 6.5.2008].

European Parliament and the Council. (2009a). Recommendation of 18 June 2009 on the Establishment of the European Credit System for Vocational Education and Training (ECVET) [OJ C 155/11 of 8.7.2009].

European Parliament and the Council. (2009b). Recommendation of the European Parliament and of the Council of 18 June 2009 on the establishment of a European Quality Assurance Reference Framework for Vocational Education and Training [OJ C 155/1 of 8.7.2009].

Eurostat. (2013). Unemployment rates, seasonally adjusted, September 2013 - Statistics Explained (2013/11/2). Retrieved November 3, 2013, from http://epp.eurostat.ec.europa.eu/statistics_explained/index.php /Unemployment_statistics

Farooq, G. M., \& Ofosu, Y. (1992). Population, labour force and employment: Concepts, trends and policy issues. Background Papers for Training in Population, Human Resources and Development Planning, No. 9, Geneva: International Labour Organization (ILO).

Feinstein, L., Budge, D., Vorhaus, J., \& Duckworth, K. (2008). The social and personal benefits of learning: A summary of key research findings. London: Centre for Research on the Wider Benefits of Learning (Institute of Education, University of London). Retrieved January 30, 2014, from http://www.learningbenefits.net/Publications/FlagshipPubs/Final\%20WBL\%20Synthesis\%20Report.pdf

Giddens, A. (1994). Beyond Left and Right. The Future of Radical Politics. Cambridge: Polity.

Görlich, D., Stepanok, I., \& Al-Hussami, F. (2013). Youth Unemployment in Europe and the World: Causes, Consequences and Solutions. Kiel Policy Brief No. 59 (January 2013), Kiel: Kiel Institute for the World Economy. Retrieved November 15, 2013, from http://www.ifw-kiel.de/wirtschaftspolitik/politikberatung /kiel-policy-brief/KPB_59.pdf

Harbison, F. H. (1973). Human Resources as the Wealth of Nations. New York: Oxford University Press.

Harbison, F. H., \& Meyers, C. A. (1964). Education, Manpower and Economic Growth. Strategies of Human Resource Development. New York: McGraw-Hill.

Harman, C., \& Brelade, S. (2000). Knowledge Management and the role of HR. Securing competitive advantages in the knowledge economy. London: Financial Times-Prentice Hall.

Helsinki Communiqué. (2006). On Enhanced European Cooperation in Vocational Education and Training, Communiqué of the European Ministers of Vocational Education and Training, the European Social partners and the European Commission, convened in Helsinki on 5 December 2006 to review the priorities and strategies of the Copenhagen Process. Retrieved 23 October 2013 from $\mathrm{http} / / /$ ec.europa.eu/education/lifelong-learning-policy/doc/vocational/helsinki_en.pdf

International Labour Organization. (2013). Global Employment Trends 2013; Recovering from a second jobs dip. Geneva: International Labour Office.

Lisbon European Council. (23-24 March 2000). Presidency conclusions. Retrieved October 15, 2013, from http://www.consilium.europa.eu/uedocs/cms_data/docs/pressdata/en/ec/00100-r1.en0.htm

Lloyd, C., \& Payne, J. (2002). Developing a Political Economy of Skill. Journal of Education and Work, 15(4), 365-390. http://dx.doi.org/10.1080/1363908022000023533

Maastricht Communiqué. (2004). Council of the European Union, European Social Partners and the European Commission (2004), Maastricht Communiqué of 14 December 2004 on the Future Priorities of Enhanced European Cooperation in Vocational Education and Training (VET) (Review of the Copenhagen Declaration of 30 November 2002). Retrieved October 23, 2013 from http://ec.europa.eu/education/news /ip/docs/maastricht_com_en.pdf. 
McFarland, L., \& Vickers, M. (1994). The Context and Rationale for the Reform of Vocational and Technical Education. In OECD, Vocational Education and Training for Youth: Towards a Coherent Policy and Practice (pp. 7-18). Washington: United States Ministry of Education and Paris: OECD. Retrieved January 28, 2014, from http://books.google.gr/books?id=zG5Aqis84MwC\&printsec=frontcover\&hl=el\&source $=$ gbs_ge_summary_r\&cad $=0 \# v=$ onepage $\& \mathrm{q} \& \mathrm{f}=$ false

McGrath, S. (2012). Vocational Education and Training for Development: A Policy in need of a Theory?. International Journal of Educational Development 32, 623-631. http://dx.doi.org/10.1016/j.ijedudev.2011.12.001

McGrath, S., \& Lugg, R. (2012). Knowing and doing vocational education and training reform: Evidence, learning and the policy process. International Journal of Educational Development 32, 696-708. http://dx.doi.org/10.1016/j.ijedudev.2012.02.004

Middleton, J., Ziderman, A., \& Van Adams, A. (1992). The World Bank's policy on vocational and Technical Education and Training. Prospects Quarterly Review of Education, Vol. XXII, No. 2, (82), 127-140. Retrieved January 24, 2014, from http://unesdoc.unesco.org/images/0009/000952/095257eo.pdf

Mouzakitis, G. (2010). The role of vocational education and training curricula in economic development. Procedia Social and Behavioral Sciences, 2, 3914-3920. http://dx.doi.org/10.1016/j.sbspro.2010.03.616

Not in Education, Employment or Training: Europe's lost NEET generation detailed. (2012, October 22). The Guardian (on-line edition). Retrieved October 10, 2013, from http://www.guardian.co.uk/news/datablog /2012/oct/22/not-in-education-employment-training-europe-neet\#

OECD. (1998). Pathways and Participation in Vocational and Technical Education and Training. Paris: OECD.

Ploteus portal (a Portal on Learning Opportunities throughout Europe). Retrieved from http://ec.europa.eu /ploteus/about_en.htm

Psacharopoulos, G. (1997). Vocational Education and Training Today: Challenges and Responses. Journal of Vocational Education \& Training, 49(3), 385-393. http://dx.doi.org/10.1080/13636829700200022

Schultz, T. W. (1971). Investment in Human Capital. The Role of Education and Research. The Free Press.

Schultz, T. W. (1981). Investing in People. The Economics of Population Quality. Berkeley, Los Angeles, London: University of California Press.

Shane, S., Locke, E. A., \& Collins, C. J. (2003). Entrepreneurial Motivation. Human Resource Management Review, 13, 257-279. http://dx.doi.org/10.1016/S1053-4822(03)00017-2

Treaty of Amsterdam. (1997). Amending the Treaty on European Union, the Treaties establishing the European Communities and related acts. Official Journal C 340, 10 November 1997.

UNESCO. (2012a). Youth and Skills. Putting Education to Work. EFA Global Monitoring Report. Unesco. Retrieved January 29, 2014, from http://unesdoc.unesco.org/images/0021/002180/218003e.pdf

UNESCO. (2012b). General Report of the Third International Congress on Technical and Vocational Education and Training on "Transforming TVET: Building skills for work and life". Shanghai, People's Republic of China (14-16 May 2012). Retrieved January 31, 2014, from http://www.unesco.org/new/fileadmin/MULTIMEDIA/HQ/ED/pdf/Final_General_Report_English.pdf

UNESCO. (2012c). Transforming Technical and Vocational Education and Training. Building skills for work and life. Main Working Document for the Third International Congress on Technical and Vocational Education and Training (Shanghai, People's Republic of China, 13-16 May 2012). UNESCO. Retrieved January 31, 2014, from http://unesdoc.unesco.org/images/0021/002160/216065e.pdf

UN General Assembly. (2001). Road map towards the implementation of the United Nations Millennium Declaration. Report of the Secretary-General, A/56/326 ('The Millennium Development Goals-MDGs'). Retrieved January 31, 2014, from http://www.un.org/millenniumgoals/sgreport2001.pdf?OpenElement

UNICA et al. (Eds.) (2010). ECVET-ECTS: Building Bridges and Overcoming Differences. A Methodological Guide Produced in the Framework of the Be-TWIN Project (July 2010).

World Bank. (1991). WDR 1991: The Challenge of Development. World Bank and Oxford University Press. Retrieved January 28, 2014, from https://openknowledge.worldbank.org/bitstream/handle/10986 /5974/WDR\%201991\%20-\%20English.pdf?sequence=1 


\section{Notes}

Note 1. China, India, Russia, Brazil, South Africa (BRICS) and others have contributed to the transfer of the economic activity to new centers and the decline of the European economy, which resulted-among others-in the deterioration of employment conditions.

Note 2. The Lisbon European Council (23-24 March 2000) set the main goal regarding employment to raise its overall rate to $70 \%$ (and for females to 60\%) by 2010; at the Barcelona European Council (15-16 March 2002) new mid-term goals were set for overall and female employment to $67 \%$ and $57 \%$ respectively by 2005 , when a new assessment would reconsider and update the adapted policy measures.

Note 3. The other three targets refer to R\&D/innovation, Climate change/energy and Poverty/social exclusion.

Note 4. Five of the 'Europe 2020' flagships depend on/are related to the modernisation of education and training: Youth on the Move, Agenda for New Skills and Jobs, as well as the Digital Agenda, Innovation Union and the Platform against Poverty.

Note 5. The term refers to young people 15-29 years old who remain out of the labour market for various reasons; they also do not participate in any education and training activities which would strengthen their opportunities to enter or re-enter the labour market.

Note 6.Figure 3 is part of an article about NEETs which was published in The Guardian on 22 October 2012. It is based on data of Eurofound, an EU research agency that specialises in the area of social and work-related policies.

Note 7. In Greece, for example, such initiatives are undertaken by the 'Youth Entrepreneurship' Society (SEN/JA Greece, www.sen.org.gr) which participates in the European network 'Junior Achievement-Young Enterprise' (JA-YE, www.ja-ye.org).

Note 8 . The development of open learning approaches and of trainers' competences by providing the appropriate learning environment in educational or working environment settings were considered very important.

Note 9. Although until then mobility in the educational systems had been confined to strictly specified pathways and the cooperation between the bodies held accountable for each educational stream was rather limited, the Maastricht Communiqué introduced the idea that mobility between different levels and forms of education/training would be possible.

Note 10. The Europass CV and the Language Portfolio are completed by the individual concerned; the Europass Mobility, the Diploma Supplement (for tertiary education) and the Certificate Supplement (for VET) are issued by national or VET authorities.

Note 11. It must be emphasised that the ECVET system was based on the same fundamental idea with the European Credit Transfer and Accumulation System (ECTS) that is applied to university studies. ECTS was introduced to tertiary education institutions in order to facilitate the recognition of tertiary education learning between different institutions and, therefore, to improve the quality of studies and to enhance student mobility in European countries for part of their studies.

Note 12. Finland, UK, Austria, Norway and Sweden have already tested similar market measures and can project their experience so that the new EU initiative can be successful.

\section{Copyrights}

Copyright for this article is retained by the author(s), with first publication rights granted to the journal.

This is an open-access article distributed under the terms and conditions of the Creative Commons Attribution license (http://creativecommons.org/licenses/by/3.0/). 